\title{
The effect of dietary cation-anion difference concentration and cation source on milk production and feed efficiency in lactating dairy cows
}

\author{
M. E. Iwaniuk, A. E. Weidman, and R. A. Erdman ${ }^{1}$ \\ Animal and Avian Sciences Department, University of Maryland, College Park 20742
}

\begin{abstract}
Feed costs currently account for $55 \%$ or more of the total cost of milk production in US dairy herds, and dairy producers are looking for strategies to improve feed efficiency [FE; 3.5\% fat-corrected milk (FCM) per dry matter (DM) intake]. Increasing dietary cation-anion difference [DCAD; $\mathrm{Na}+\mathrm{K}-\mathrm{Cl}(\mathrm{mEq} / \mathrm{kg}$ of $\mathrm{DM})$ ] has been shown to increase milk production, FCM, and FE. However, the optimal DCAD concentration for maximal $\mathrm{FE}$ has yet to be determined. The objectives of this research were to test the effects of DCAD concentration and cation source on dairy FE. Sixty Holstein dairy cows (20 cows per experiment) were used in three $4 \times 4$ Latin square design experiments with 3 -wk experimental periods. In experiments 1 and 2, we tested the effect of DCAD concentration: cows were fed a basal diet containing $\sim 250 \mathrm{mEq} / \mathrm{kg}$ of DM DCAD that was supplemented with potassium carbonate at 0 , 50,100 , and $150 \mathrm{mEq} / \mathrm{kg}$ of $\mathrm{DM}$ or $0,125,250$, and 375 $\mathrm{mEq} / \mathrm{kg}$ of $\mathrm{DM}$ in experiments 1 and 2, respectively. In experiment 3 , we tested the effect of cation source: sodium sesquicarbonate replaced $0,33,67$, and $100 \%$ of the supplemental potassium carbonate $(150 \mathrm{mEq} / \mathrm{kg}$ of DM DCAD). The DCAD concentration had no effect on milk production, milk protein concentration, or milk protein yield in experiments 1 and 2. Dry matter intake was not affected by DCAD concentration in experiment 1 or by cation source in experiment 3. However, DMI increased linearly with increasing DCAD in experiment 2. We detected a linear increase in milk fat concentration and yield with increasing DCAD in experiments 1 and 2 and by substituting sodium sesquicarbonate for potassium carbonate in experiment 3 . Increased milk fat concentration with increasing DCAD led to increases in $3.5 \%$ FCM in experiments 1 and 2. Maximal dairy FE was achieved at a DCAD concentration of $426 \mathrm{mEq} / \mathrm{kg}$ of DM in experiments 1 and 2 and by substituting $\mathrm{Na}$ for $\mathrm{K}$ in experiment 3 . The results of these experiments suggest that both DCAD concentration and the cation
\end{abstract}

Received August 4, 2014.

Accepted November 10, 2014.

${ }^{1}$ Corresponding author: erdman@umd.edu source used to alter DCAD concentration have effects on milk fat content and yield and dairy FE.

Key words: dietary cation-anion difference, feed efficiency, dairy cow

\section{INTRODUCTION}

Dairy feed costs are the largest single expense associated with producing milk (Wolf, 2010; Buza et al., 2014) and have accounted for $55 \%$ or more of the total cost of milk production in US dairy herds over the last 4 yr (USDA-NASS, 2014). The use of corn for ethanol production coupled with the severe drought during the 2012 growing season nearly doubled purchased feed costs to dairy and livestock producers (USDA-ERS, 2013). Thus, there is renewed interest among dairy producers in feeding strategies that improve feed utilization and increase milk output per unit feed input.

Erdman et al. (2011) and Harrison et al. (2012) demonstrated improved FE in lactating dairy cows by increasing DCAD $(\mathrm{Na}+\mathrm{K}-\mathrm{Cl})$ using potassium carbonate $\left(\mathrm{K}_{2} \mathrm{CO}_{3}\right)$ and potassium carbonate sesquihydrate $\left(\mathrm{K}_{2} \mathrm{CO}_{3} \cdot 1.5 \mathrm{H}_{2} \mathrm{O}\right)$ supplementation, respectively. Dairy feed efficiency (FE) measured as 3.5\% FCM/DMI was improved by $7.7 \%$ (0.14 units) when the DCAD concentration increased from 251 to $336 \mathrm{mEq} / \mathrm{kg}$ of $\mathrm{DM}$ using $\mathrm{K}_{2} \mathrm{CO}_{3}$ supplementation (Erdman et al., 2011). Similarly, Harrison et al. (2012) reported a 6.7\% (0.11 unit) increase in FE by increasing DCAD from 463 and $665 \mathrm{mEq} / \mathrm{kg}$ of DM using $\mathrm{K}_{2} \mathrm{CO}_{3} \cdot 1.5 \mathrm{H}_{2} \mathrm{O}$. Erdman et al. (2011) reported that $\mathrm{K}$ addition reduced feed costs by approximately $\$ 1 /$ cow per day - a $\$ 365,000$ reduction for a 1,000-cow dairy. Other work has shown that increasing DCAD improved acid-base balance, which resulted in increased DMI, milk yield, and milk fat yield (Sanchez and Beede, 1996; Hu and Murphy, 2004; Hu et al., 2007b).

Although Erdman et al. (2011) and Harrison et al. (2012) illustrated the potential for K supplementation to increase dairy FE, the optimal DCAD concentration for maximal $\mathrm{FE}$ has not been determined. The NRC (2001) nutrient requirements for a 680-kg dairy cow producing $45 \mathrm{~kg} / \mathrm{d}$ milk with $3.5 \%$ fat suggest minimal dietary concentrations of $1.06,0.22$, and $0.28 \%$ for $\mathrm{K}$, $\mathrm{Na}$, and $\mathrm{Cl}$, respectively. This is equivalent to a DCAD 
concentration of $296 \mathrm{mEq} / \mathrm{kg}$ of DM using the DCAD equation $\mathrm{DCAD}(\mathrm{mEq} / \mathrm{kg}$ of $\mathrm{DM})=(\mathrm{Na}+\mathrm{K}-\mathrm{Cl})$. In a meta-analysis, Hu and Murphy (2004) reported that milk yield was greatest when the DCAD $(\mathrm{Na}+$ $\mathrm{K}-\mathrm{Cl}$ ) concentration was $340 \mathrm{mEq} / \mathrm{kg}$ of $\mathrm{DM}, 4.0 \%$ FCM production was highest at $490 \mathrm{mEq} / \mathrm{kg}$ of $\mathrm{DM}$ DCAD, and DMI was maximized at $400 \mathrm{mEq} / \mathrm{kg}$ of DM DCAD. Sanchez and Beede (1996) suggested that both milk yield and DMI were maximized at a DCAD $(\mathrm{Na}+\mathrm{K}-\mathrm{Cl})$ concentration equal to $380 \mathrm{mEq} / \mathrm{kg}$ of DM. Although several studies have investigated production responses to various DCAD concentrations, the optimal DCAD concentration for maximal dairy FE is unknown. Therefore, the objective of experiments 1 and 2 was to determine the optimal DCAD concentration required to maximize $\mathrm{FE}$.

In most lactating dairy cow diets, $\mathrm{K}$ is the predominant cation because of the high concentrations of $\mathrm{K}$ in forages (NRC, 2001). However, the strong ion theory upon which the DCAD principle of diet formulation is based suggests that $\mathrm{Na}$ or $\mathrm{K}$ would be equally effective. Some previous research suggested that milk yield and milk composition were not affected by cation source and that the most important influence on production responses is the overall DCAD concentration (Tucker et al., 1988a; West et al., 1992; Hu and Kung, 2009). However, other studies have reported that there may be significant interactions affecting the milk yield and DMI response to DCAD with different ratios of Na:K in the diet (Sanchez et al., 1994, 1997). Increasing dietary DCAD using $\mathrm{K}$ supplements such as $\mathrm{K}_{2} \mathrm{CO}_{3}$ is typically 3 to 4 times more expensive (per kilogram basis) than $\mathrm{Na}$ supplementation using sodium bicarbonate $\left(\mathrm{NaHCO}_{3}\right)$. Thus, in addition to knowing the optimal DCAD concentration for maximal performance and $\mathrm{FE}$, the relative effectiveness of $\mathrm{Na}$ versus $\mathrm{K}$ as strong ion sources is economically important. Therefore, the objective of experiment 3 was to compare the relative effectiveness of $\mathrm{Na}$ and $\mathrm{K}$ as cation sources when used to increase DCAD.

\section{MATERIALS AND METHODS}

\section{Research Facilities and Animals}

The experiments conducted in this report were approved by the University of Maryland Animal Care and Use Committee. Three $4 \times 4$ Latin square design experiments were conducted using 60 Holstein dairy cows (20 cows; 8 primiparous and 12 multiparous per experiment). At the start of the experiments, cows produced $39.9 \pm 1.6,39.8 \pm 1.9$, and $41.4 \pm 1.4 \mathrm{~kg} / \mathrm{d}$ of milk, and were $89 \pm 25,95 \pm 75$, and $95 \pm 25$ DIM in experiments 1,2 , and 3 , respectively.
Cows were housed and individually fed in tie-stalls fitted with water mattresses (Ryder Supply Company, Chambersburg, PA) that were bedded with wood shavings. Lighting in the research barn was controlled such that the cows received a minimum of $12 \mathrm{~h} / \mathrm{d}$ of light during each study. Cows had continuous access to water via shared drinking cups in their tie stalls. Cows were milked twice daily at approximately 0630 and $1600 \mathrm{~h}$. Experiments 1 and 2 were conducted from late-January to mid-April (2012 and 2013, respectively), and experiment 3 was conducted from mid-May to late-July 2012.

\section{Experimental Diets and Feeding}

Three basal TMR were formulated to meet or exceed the NRC (2001) nutrient requirements for dairy cows producing $40 \mathrm{~kg} / \mathrm{d}$ milk containing $3.7 \%$ fat and $3.1 \%$ protein (Table 1). The basal TMR contained 60, 65, and $69 \%$ forage (DM basis) and 40, 35, and 32\% concentrate in experiments 1,2 , and 3 , respectively. In experiments 1 and 3, forage consisted of only corn silage; however, in experiment 2, forage consisted of 62 to $64 \%$ corn silage and $6 \%$ alfalfa hay. In all experiments, the concentrate portion comprised ground shelled corn and soybean meal ( $48 \% \mathrm{CP}$, as-fed basis) with the remainder of the ingredients (Table 1), including corn gluten meal, macro and trace mineral supplements, rumen-protected fat (Megalac, Arm and Hammer Animal Nutrition, Piscataway, NJ), and feed additives (Table 1), combined and added as a premix in the TMR.

In experiment 1, treatments consisted of a basal diet formulated to contain approximately $250 \mathrm{mEq} / \mathrm{kg}$ of DM DCAD (Table 1) or the basal diet plus 50, 100, and $150 \mathrm{mEq} / \mathrm{kg}$ of DM added DCAD using supplemental feed-grade $\mathrm{K}_{2} \mathrm{CO}_{3}$ (DCAD Plus, Church \& Dwight Co. Inc., Piscataway, NJ) that resulted in final estimated DCAD of approximately 250,300, 350, and $400 \mathrm{mEq} /$ $\mathrm{kg}$ of DM (Table 1). The DCAD concentrations selected for experiment 1 were designed to be below and above the $296 \mathrm{mEq} / \mathrm{kg}$ suggested by the NRC (2001) and to reflect DCAD concentrations found in typical lactating dairy cow rations as well as DCAD concentrations that have been shown in other studies to optimize response variables such as milk yield and DMI (Sanchez and Beede, 1996; Hu and Murphy, 2004).

Similarly, in experiment 2, treatments consisted of a basal diet containing approximately $250 \mathrm{mEq} / \mathrm{kg}$ of DM DCAD (Table 2) or the basal diet plus 125, 250, and $375 \mathrm{mEq} / \mathrm{kg}$ of DM added DCAD using supplemental $\mathrm{K}_{2} \mathrm{CO}_{3}$, which resulted in final estimated DCAD of approximately $250,375,500$, and $625 \mathrm{mEq} / \mathrm{kg}$ of DM (Table 1). The DCAD concentrations chosen for experiment 2 were selected to provide larger incremental increases in DCAD compared with experiment 1. 
Table 1. Ingredient composition of experimental diets (DM basis)

Experiment 1

Added DCAD $(\mathrm{mEq} / \mathrm{kg} \text { of } \mathrm{DM})^{1}$

z Corn silage

Ground corn

Soybean meal, $48 \%$

Potassium carbonate ${ }^{3}$

Sodium sesquicarbonate ${ }^{4}$

Corn gluten meal, $60 \%$

Limestone $^{5}$

Biophos

Magnesium oxide

Dynamate $^{7}$

Salt-white

TM- $433^{8}$

4-Plex

ADE Mix ${ }^{10}$

Selenium $^{12}$

Megalac $^{13}$

Omigen- $\mathrm{AF}^{14}$

Rumensin- $22 \mathrm{~g} / \mathrm{kg}^{15}$

$\frac{\text { Experiment } 1}{\text { Added DCAD }(\mathrm{mEq} / \mathrm{kg} \text { of } \mathrm{DM})^{1}}$

\begin{tabular}{rrrr}
\multicolumn{1}{c}{0} & \multicolumn{1}{c}{50} & \multicolumn{1}{c}{100} & \multicolumn{1}{c}{150} \\
59.71 & 59.71 & 59.71 & 59.71 \\
0.00 & 0.00 & 0.00 & 0.00 \\
17.70 & 17.30 & 16.89 & 16.49 \\
18.63 & 18.63 & 18.63 & 18.63
\end{tabular}

${ }^{1}$ Supplemental DCAD $(\mathrm{mEq} / \mathrm{kg}$ of DM) calculated as follows: $\mathrm{DCAD}=\mathrm{Na}+\mathrm{K}-\mathrm{Cl}$.
Experiment 2

Added DCAD $(\mathrm{mEq} / \mathrm{kg} \text { of } \mathrm{DM})^{1}$

\begin{tabular}{cccc} 
Experiment 2 & \\
\hline & Added DCAD & $(\mathrm{mEq} / \mathrm{kg} \text { of } \mathrm{DM})^{1}$ \\
\hline
\end{tabular}

$63.80 \quad 63.30 \quad 62.70 \quad 62.20$

$\begin{array}{rrrr}63.80 & 63.30 & 62.70 & 62.20 \\ 6.00 & 5.90 & 5.90 & 5.80\end{array}$

$\begin{array}{rrrr}6.00 & 5.90 & 5.90 & 5.80 \\ 10.10 & 10.00 & 9.90 & 9.80\end{array}$

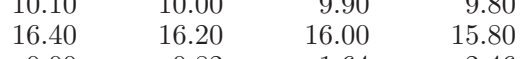

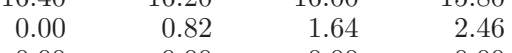

$\begin{array}{llll}0.00 & 0.00 & 0.00 & 0.00\end{array}$

$\begin{array}{llll}0.00 & 0.00 & 0.00 & 0.00 \\ 0.50 & 0.50 & 0.50 & 0.50\end{array}$

$\begin{array}{llll}0.50 & 0.50 & 0.50 & 0.50 \\ 0.52 & 0.52 & 0.52 & 0.52 \\ 0.37 & 0.37 & 0.37 & 0.37\end{array}$

$\begin{array}{llll}0.37 & 0.37 & 0.37 & 0.37 \\ 0.12 & 0.12 & 0.12 & 0.12\end{array}$

$\begin{array}{llll}0.12 & 0.12 & 0.12 & 0.12 \\ 0.13 & 0.13 & 0.13 & 0.13 \\ 0.40 & 0.40 & 0.40 & 0.40\end{array}$

$\begin{array}{llll}0.40 & 0.40 & 0.40 & 0.40 \\ 0.03 & 0.03 & 0.03 & 0.03\end{array}$

$\begin{array}{llll}0.03 & 0.03 & 0.03 & 0.03 \\ 0.03 & 0.03 & 0.03 & 0.03\end{array}$

$\begin{array}{llll}0.03 & 0.03 & 0.03 & 0.03 \\ 0.03 & 0.03 & 0.03 & 0.03 \\ 0.02 & 0.02 & 0.02 & 0.02\end{array}$

$\begin{array}{llll}0.03 & 0.03 & 0.03 & 0.03 \\ 0.02 & 0.02 & 0.02 & 0.02\end{array}$

$\begin{array}{llll}0.02 & 0.02 & 0.02 & 0.02 \\ 0.06 & 0.06 & 0.06 & 0.06\end{array}$

$\begin{array}{llll}0.06 & 0.06 & 0.06 & 0.06 \\ 1.40 & 1.40 & 1.40 & 1.40 \\ 0.20 & 0.20 & 0.20 & 0.20\end{array}$

$\begin{array}{llll}1.40 & 1.40 & 1.40 & 1.40 \\ 0.20 & 0.20 & 0.20 & 0.20\end{array}$

\begin{tabular}{rrrr}
\multicolumn{4}{c}{ Experiment 3} \\
\hline \multicolumn{5}{c}{ Supplemental DCAD K:Na ${ }^{2}$} \\
\hline $100: 0$ & $67: 33$ & $33: 67$ & $0: 100$ \\
\hline 65.00 & 65.00 & 65.00 & 65.00 \\
0.00 & 0.00 & 0.00 & 0.00 \\
11.50 & 11.44 & 11.37 & 11.31 \\
18.63 & 18.63 & 18.63 & 18.63 \\
0.91 & 0.60 & 0.30 & 0.00 \\
0.00 & 0.37 & 0.74 & 1.10 \\
0.74 & 0.74 & 0.74 & 0.74 \\
0.79 & 0.79 & 0.79 & 0.79 \\
0.10 & 0.10 & 0.10 & 0.10 \\
0.00 & 0.00 & 0.00 & 0.00 \\
0.08 & 0.08 & 0.08 & 0.08 \\
0.50 & 0.50 & 0.50 & 0.50 \\
0.02 & 0.02 & 0.02 & 0.02 \\
0.02 & 0.02 & 0.02 & 0.02 \\
0.03 & 0.03 & 0.03 & 0.03 \\
0.01 & 0.01 & 0.01 & 0.01 \\
0.05 & 0.05 & 0.05 & 0.05 \\
1.41 & 1.41 & 1.41 & 1.41 \\
0.17 & 0.17 & 0.17 & 0.17 \\
0.05 & 0.05 & 0.05 & 0.05 \\
\hline
\end{tabular}

${ }^{2}$ Each treatment diet was supplemented with $150 \mathrm{mEq} / \mathrm{kg}$ of DM with varying ratios of supplemental $\mathrm{K}: \mathrm{Na}$ ( $\mathrm{mEq} / \mathrm{kg}$ of DM) using potassium carbonate sesquihydrate and sodium sesquicarbonate as cation sources.

Each treatment contained an estimated added DCAD $(\mathrm{Na}+\mathrm{K}-\mathrm{Cl})$ of $150 \mathrm{mEq} / \mathrm{kg}$ of DM.

${ }^{3}$ Contained $56 \% \mathrm{~K}$ and $88 \%$ DM (Church \& Dwight Co. Inc., Piscataway, NJ).

${ }^{4}$ Contained $27 \% \mathrm{Na}$ (Church \& Dwight Co. Inc.).

${ }^{5}$ Contained $36 \% \mathrm{Ca}$ and $0.02 \% \mathrm{P}$.

${ }^{6}$ Contained $17 \% \mathrm{Ca}$ and $21 \% \mathrm{P}$.

${ }^{7}$ Contained $11.5 \% \mathrm{Mg}, 18 \% \mathrm{~K}$, and $22.5 \% \mathrm{~S}$ (Mosaic Co., Plymouth, MN).

${ }^{8}$ Contained $0.16 \% \mathrm{Co}, 4.0 \% \mathrm{Cu}, 3.0 \% \mathrm{Fe}, 0.35 \% \mathrm{I}, 15 \% \mathrm{Mn}$, and $16 \% \mathrm{Zn}$ (Southern States Cooperative, Inc., Richmond, VA).

${ }^{9}$ Contained $0.20 \%$ Co, $0.99 \%$ Cu, $0.031 \% \mathrm{Fe}, 1.57 \% \mathrm{Mn}$, and $2.83 \% \mathrm{Zn}$ (Southern States Cooperative Inc.).

${ }^{10}$ Contained $5,454,545 \mathrm{IU} / \mathrm{kg}$ of vitamin A, 1,818,182 IU/kg of vitamin D, 9,091 IU $/ \mathrm{kg}$ of vitamin E.

${ }^{11}$ Contained $56,818 \mathrm{IU} / \mathrm{kg}$ of vitamin E.

${ }^{12}$ Contained $0.3 \mathrm{IU} / \mathrm{g}$ of selenium, $28 \% \mathrm{Ca}$.

${ }^{13}$ Contained $9 \%$ Ca; $84.5 \%$ fat (Church \& Dwight Co. Inc.).

${ }^{14}$ Contained (per kilogram) $0.41 \mathrm{mg}$ of biotin, $15 \mathrm{mg}$ of choline, $31 \mathrm{mg}$ of D-pantothenic acid, $1.4 \mathrm{mg}$ of folic acid, $3.2 \mathrm{mg}$ of menadione, $102 \mathrm{mg}$ of niacin, $30 \mathrm{mg}$ of riboflavin, 4.5

$\times 10^{10}$ cfu of Saccharomyces cerevisiae, $15.5 \mathrm{mg}$ of thiamine, $8.2 \mathrm{mg}$ of vitamin $\mathrm{B}_{6}$, and $41 \mu \mathrm{g}$ of vitamin $\mathrm{B}_{12}$ (Prince Agri Products Inc., Quincy IL).

${ }^{15}$ Contained $20 \%$ monensin Na, $1 \%$ mineral oil, and carriers such as rice hulls, limestone, and fermentation nutrients (Elanco, Greenfield, IN). 
In experiment 3, treatments consisted of a basal diet and the addition of $150 \mathrm{mEq} / \mathrm{kg}$ of DM DCAD using 4 different ratios of added $\mathrm{K}$ and $\mathrm{Na}$ (100:0, 66.7:33.3, 33.3:66.7, and 0:100; $\mathrm{mEq} / \mathrm{kg}$ of $\mathrm{DM}$ ) using $\mathrm{K}_{2} \mathrm{CO}_{3}$ and sodium sesquicarbonate (SQ-810,Church \& Dwight Inc.) as the $\mathrm{K}$ and $\mathrm{Na}$ cation sources, respectively. Each treatment combination resulted in a final estimated DCAD of approximately $400 \mathrm{mEq} / \mathrm{kg}$ of DM (Table 1). In all experiments, treatments were applied in a 4 $\times 4$ Latin square design balanced for carryover effects with 3 -wk experimental periods. Before feeding, the basal TMR for the cows was mixed in portable mixer wagon. The treatment supplements were then added to the basal TMR and mixed in a Calan Data Ranger (American Calan, Northwood, NH) for the cows within each treatment group before delivery to individual feed tubs. Amounts of feed offered and feed refusals were recorded once daily at $0930 \mathrm{~h}$.

\section{Measurements}

Measurements included weekly individual cow BW and daily feed intake and feed refusals. Silage and concentrate samples were taken weekly for DM analysis to adjust the as-fed TMR to maintain a constant forageto-concentrate ratio and to measure feed DM such that daily DMI could be calculated for each cow. Milk production was recorded electronically at each milking at 0630 and $1600 \mathrm{~h}$. Milk samples were collected during the last 4 consecutive milkings of each experimental period (d 20 and 21) and analyzed for fat, protein, other solids (OS; lactose plus minerals), and SCC in all experiments (Lancaster Dairy Herd Information Association, Manheim, PA). Milk MUN was measured only in experiments 2 and 3 (Lancaster Dairy Herd Information Association).

Individual samples of the corn silage, ground corn, soybean meal, vitamin premix, and the treatment mixes were collected weekly and composited by experimental period for analysis of diet DM, CP, ADF, NDF, lignin, ether extract, $\mathrm{Ca}, \mathrm{P}, \mathrm{Mg}, \mathrm{Na}, \mathrm{K}, \mathrm{Cl}$, and $\mathrm{S}$ at a commercial laboratory (Cumberland Valley Analytical Services, Hagerstown, MD). Actual DCAD was calculated based on the $\mathrm{K}, \mathrm{Na}$, and $\mathrm{Cl}$ concentrations of the individual feeds or mixtures weighted proportionally to their contribution to the diet DM in the TMR.

\section{Statistical Model}

Mean data for DMI, milk production, fat and protein percentages, SCC, MUN, fat and protein yields, 3.5\% FCM, and FE for each cow from the last week of each experimental period were used in the statistical analyses. Data from each experiment were analyzed using
PROC MIXED in SAS (version 9.3; SAS Institute Inc., Cary, NC) with the statistical model

$$
\mathrm{Y}_{\mathrm{ijk}}=\mu+\mathrm{C}_{\mathrm{i}}+\mathrm{P}_{\mathrm{j}}+\mathrm{T}_{\mathrm{k}}+\mathrm{e}_{\mathrm{ijk}}
$$

where $Y_{\mathrm{ijk}}=$ the response from the ith cow, the jth period, and the kth treatment; $\mu=$ the grand mean; $\mathrm{C}_{\mathrm{i}}$ $=$ the effect of the ith cow; $\mathrm{P}_{\mathrm{j}}=$ the effect of the jth period; $\mathrm{T}_{\mathrm{k}}=$ the effect of the kth treatment level; and $\mathrm{e}_{\mathrm{ijk}}=$ random error.

Treatment was analyzed as a fixed effect, whereas cow and period were analyzed as random effects. In experiments 1 and 2 , the treatments were designed to provide $50 \mathrm{mEq} / \mathrm{kg}$ of $\mathrm{DM}$ and $125 \mathrm{mEq} / \mathrm{kg}$ of $\mathrm{DM}$ increments in DCAD, respectively, such that the dose response to DCAD concentration was tested. In experiment 3 , the treatments were designed to provide equidistant substitution of $\mathrm{Na}$ for $\mathrm{K}$ at a constant rate of supplemental DCAD such that the production responses to K versus Na could be tested. Therefore, both linear and quadratic orthogonal contrasts were tested in all 3 experiments. In all studies, a probability of $P$ $\leq 0.05$ was considered statistically significant, whereas probabilities of $P \leq 0.10$ were considered trends.

To determine the dose response to DCAD, treatment means for FCM, milk fat yield, milk yield, and FE from experiments 1 and 2 were pooled and fitted by quadratic regression. To account for differences in production and FE between experiments 1 and 2, individual study effects were quantified as random effects using PROC MIXED (version 9.3; SAS Institute Inc.), and studyadjusted means were calculated at each DCAD concentration. Using the study-adjusted values, quadratic regression analysis was conducted using PROC REG (version 9.3; SAS Institute Inc.) to determine the dose response to DCAD concentrations for each variable.

\section{RESULTS}

\section{Experiments 1 and 2: Optimal DCAD Concentration}

The ingredient and chemical composition (DM basis) of the dietary treatments from experiment 1 and 2 are presented in Tables 1 and 2, respectively. As expected, diets within each study were similar in chemical composition except for K and DCAD. Dietary K increased linearly from 1.30 to $1.79 \%$ and from 1.29 to $2.64 \%$ in experiments 1 and 2, respectively. Measured DCAD concentrations in the treatment diets were 277,319 , 368 , and $406 \mathrm{mEq} / \mathrm{kg}$ of DM in experiment 1 and 257 , 360,488 , and $603 \mathrm{mEq} / \mathrm{kg}$ of $\mathrm{DM}$ in experiment 2. The range in measured DCAD concentrations among treatments was $129 \mathrm{mEq} / \mathrm{kg}$ of DM in experiment 1 and 346 $\mathrm{mEq} / \mathrm{kg}$ of DM in experiment 2, being somewhat lower 
Table 2. Chemical composition of experimental diets (DM basis)

\begin{tabular}{|c|c|c|c|c|c|c|c|c|c|c|c|c|c|c|c|}
\hline \multirow[b]{3}{*}{ Item } & \multicolumn{5}{|c|}{ Experiment 1} & \multicolumn{5}{|c|}{ Experiment 2} & \multicolumn{5}{|c|}{ Experiment 3} \\
\hline & \multicolumn{5}{|c|}{ Added DCAD $(\mathrm{mEq} / \mathrm{kg} \text { of } \mathrm{DM})^{1}$} & \multicolumn{5}{|c|}{ Added DCAD $(\mathrm{mEq} / \mathrm{kg} \text { of } \mathrm{DM})^{1}$} & \multicolumn{5}{|c|}{ Supplemental DCAD K: $\mathrm{Na}^{2}$} \\
\hline & 0 & 50 & 100 & 150 & SEM & 0 & 125 & 250 & 375 & SEM & 100:0 & $67: 33$ & $33: 67$ & $0: 100$ & SEM \\
\hline I $(\%)$ & 47.9 & 47.9 & 47.9 & 47.9 & 0.004 & 53.7 & 54 & 54.2 & 54.5 & 0.182 & 52.9 & 52.8 & 52.7 & 52.7 & 0.050 \\
\hline $\mathrm{NE}_{\mathrm{L}}$ (Mcal $/ \mathrm{kg}$ ) & 1.74 & 1.73 & 1.72 & 1.72 & 0.003 & 0.73 & 0.73 & 0.73 & 0.73 & 0.083 & 0.77 & 0.77 & 0.77 & 0.77 & -3 \\
\hline $\mathrm{CP}(\%)$ & 16.3 & 16.3 & 16.2 & 16.2 & 0.019 & 15.7 & 15.6 & 15.4 & 15.3 & 0.113 & 15.9 & 15.9 & 15.9 & 15.9 & 0.003 \\
\hline NDF (\%) & 26.7 & 26.7 & 26.6 & 26.6 & 0.025 & 33.6 & 33.4 & 33.1 & 32.8 & 0.178 & 27.1 & 27.1 & 27.1 & 27.1 & 0.003 \\
\hline $\mathrm{DF}(\%)$ & 15.3 & 15.3 & 15.3 & 15.3 & 0.006 & 21.3 & 21.1 & 20.9 & 20.8 & 0.018 & 17 & 17 & 17 & 17 & 0.003 \\
\hline Lignin (\%) & 2.29 & 2.28 & 2.27 & 2.26 & 0.006 & 3.45 & 3.42 & 3.39 & 3.36 & 0.015 & 2.37 & 2.37 & 2.37 & 2.37 & - \\
\hline Ash (\%) & 5.53 & 5.82 & 6.32 & 6.47 & 0.218 & 6.01 & 5.96 & 5.91 & 5.86 & 0.032 & 7.13 & 7.12 & 7.21 & 7.23 & 0.028 \\
\hline Fat $^{4}(\%)$ & 2.3 & 2.27 & 2.25 & 2.23 & 0.015 & 2.84 & 2.81 & 2.79 & 2.77 & 0.005 & 0.02 & 0.02 & 0.02 & 0.02 & - \\
\hline $\mathrm{Na}(\%)$ & 0.24 & 0.24 & 0.25 & 0.25 & 0.003 & 0.17 & 0.17 & 0.17 & 0.17 & 0.002 & 0.26 & 0.39 & 0.57 & 0.71 & 0.099 \\
\hline$(\%)$ & 1.30 & 1.46 & 1.64 & 1.79 & 0.107 & 1.29 & 1.69 & 2.19 & 2.64 & 0.002 & 1.79 & 1.57 & 1.39 & 1.19 & 0.128 \\
\hline $\mathrm{Cl}(\%)$ & 0.57 & 0.57 & 0.57 & 0.57 & - & 0.53 & 0.52 & 0.52 & 0.51 & 0.293 & 0.55 & 0.55 & 0.55 & 0.55 & - \\
\hline $5(\%)$ & 0.18 & 0.18 & 0.18 & 0.18 & - & 0.2 & 0.19 & 0.19 & 0.19 & 0.001 & 0.18 & 0.18 & 0.18 & 0.18 & - \\
\hline a $(\%)$ & 0.75 & 0.75 & 0.75 & 0.75 & - & 0.86 & 0.86 & 0.85 & 0.84 & 0.001 & 0.7 & 0.7 & 0.7 & 0.7 & - \\
\hline$(\%)$ & 0.38 & 0.38 & 0.38 & 0.38 & - & 0.43 & 0.43 & 0.43 & 0.42 & 0.003 & 0.38 & 0.38 & 0.38 & 0.38 & - \\
\hline $\operatorname{Mg}(\%)$ & 0.2 & 0.2 & 0.19 & 0.19 & 0.003 & 0.29 & 0.29 & 0.29 & 0.29 & - & 0.18 & 0.18 & 0.18 & 0.18 & - \\
\hline DCAD $(\mathrm{mEq} / \mathrm{kg} \text { of } \mathrm{DM})^{5}$ & 277 & 319 & 368 & 406 & 13.0 & 257 & 360 & 488 & 603 & 74.5 & 416 & 416 & 448 & 458 & 5.17 \\
\hline DCAD-S $(\mathrm{mEq} / \mathrm{kg} \text { of DM })^{6}$ & 164 & 205 & 255 & 293 & 13.0 & 196 & 312 & 428 & 544 & 74.8 & 360 & 360 & 392 & 402 & 5.14 \\
\hline
\end{tabular}

${ }^{1}$ Supplemental DCAD from potassium carbonate calculated as DCAD $=\mathrm{Na}+\mathrm{K}-\mathrm{Cl}(\mathrm{mEq} / \mathrm{kg}$ of $\mathrm{DM})$.

${ }^{2}$ Each treatment diet was supplemented with $150 \mathrm{mEq} / \mathrm{kg}$ of DM with varying ratios of supplemental K:Na (mEq/kg of DM) using potassium carbonate sesquihydrate and sodium sesquicarbonate as cation sources.

${ }^{3}$ Dash indicates SEM $<0.001$.

${ }^{4}$ Measured as crude fat, which would not include the $1.19 \%$ fatty acids from Megalac (Arm and Hammer Animal Nutrition, Piscataway, NJ).

${ }^{5}$ Dietary $\mathrm{Na}+\mathrm{K}-\mathrm{Cl}$.

${ }^{6}$ Dietary $\mathrm{Na}+\mathrm{K}-\mathrm{Cl}-\mathrm{S}$. 
than the expected ranges of 150 and $375 \mathrm{mEq} / \mathrm{kg}$ of DM, respectively.

The DCAD concentration had no effect $(P>0.05)$ on BW, milk production, or milk protein yield (Table $3)$. However, we observed a trend $(P=0.067)$ for reduced milk protein percentage with increased DCAD in experiment 1. Dry matter intake was not affected by DCAD concentration in experiment 1 . However, in experiment 2, DMI increased linearly in response to increasing DCAD $(P<0.05)$. In addition, increasing DCAD in experiment 2 resulted in a significant decrease in MUN $(P=0.001)$. The DCAD had no effect on OS percentage, OS yield, or SCC $(P>0.05)$.

In experiments 1 and 2 , milk fat percentage increased linearly with increasing DCAD $(P<0.05)$ such that fat percentage was highest (2.86 and $3.62 \%$, respectively) in cows fed the highest DCAD concentrations in each experiment (406 and $603 \mathrm{mEq} / \mathrm{kg}$ of DM, respectively). Milk fat yield increased linearly in response to increased DCAD $(P<0.05)$ in experiment 1 , in which fat yield was highest $(1,108 \mathrm{~g} / \mathrm{d})$ at a measured DCAD concentration of $406 \mathrm{mEq} / \mathrm{kg}$ of DM. In experiment 2, fat yield was both linearly $(P<0.001)$ and quadratically $(P=0.048)$ altered by DCAD such that the maximal fat yield $(1,379 \mathrm{~g} / \mathrm{d})$ occurred at a measured DCAD of $603 \mathrm{mEq} / \mathrm{kg}$ of DM.

Yields of $3.5 \%$ FCM linearly increased $(P<0.05)$ with increasing DCAD in both experiments. However, a quadratic effect of DCAD on $3.5 \%$ FCM was observed in experiment $2(P<0.05)$, in which $3.5 \% \mathrm{FCM}$ reached a plateau at a DCAD concentration of $360 \mathrm{mEq} / \mathrm{kg}$ of DM. In experiment 1, the increase in $3.5 \% \mathrm{FCM}$ at a constant DMI resulted in a linear increase in $\mathrm{FE}(P=$ 0.042 ), with the greatest FE shown in the $406 \mathrm{mEq} / \mathrm{kg}$ of DM treatment. However, the DCAD concentration required for maximal $\mathrm{FE}$ could not be determined from experiment 1 because the highest treatment DCAD concentration yielded the maximum FE. In experiment 2, DMI increased linearly with DCAD but $3.5 \% \mathrm{FCM}$ plateaued at $360 \mathrm{mEq} / \mathrm{kg}$ of $\mathrm{DM}$, which resulted in a FE that was greatest at DCAD concentrations of 360 and $488 \mathrm{mEq} / \mathrm{kg}$ of $\mathrm{DM}$, but the differences in FE only trended toward significance (quadratic, $P=0.085$ ).

\section{Experiment 3: Cation Source}

The ingredient and chemical composition of the dietary treatments in experiment 3 are presented in Tables 1 and 2, respectively. As expected, diets were similar in chemical composition (Table 2) except for $\mathrm{Na}$ and K. Calculated treatment DCAD concentrations (using the $\mathrm{Na}+\mathrm{K}-\mathrm{Cl}$ equation) were $417,418,447$, and $457 \mathrm{mEq} / \mathrm{kg}$ of DM for the 100:0, 67:33, 33:67, and $0: 100 \mathrm{~K}: \mathrm{Na}$ treatments. Although the diets were ex-

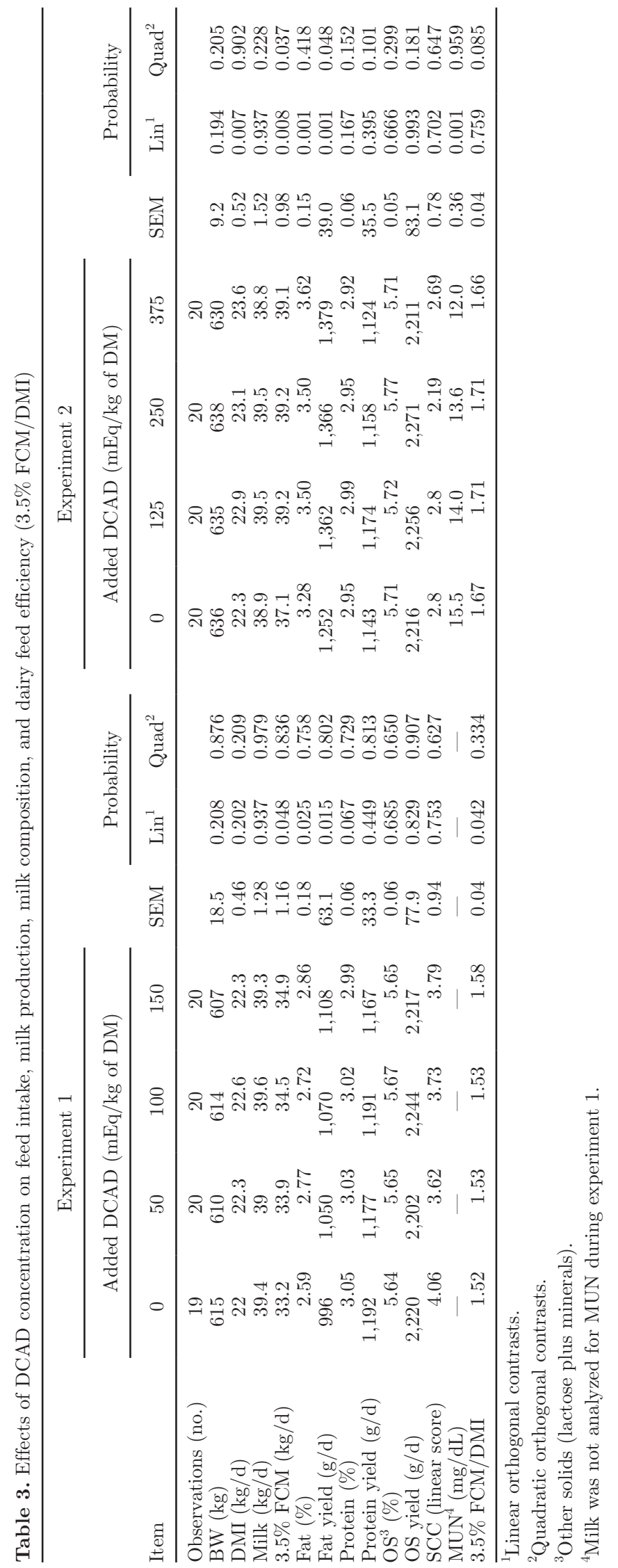

Journal of Dairy Science Vol. 98 No. 3, 2015 
Table 4. Relative effectiveness of cation source on feed intake, milk production, milk composition, and dairy feed efficiency (3.5\% FCM/DMI) in experiment $3^{1}$

\begin{tabular}{|c|c|c|c|c|c|c|c|}
\hline Item & \multicolumn{4}{|c|}{$\mathrm{K}: \mathrm{Na}$ ratio of supplement } & SEM & \multicolumn{2}{|c|}{ Probability } \\
\hline DMI $(\mathrm{kg} / \mathrm{d})$ & 22.3 & 22.3 & 22.1 & 22.0 & 0.46 & 0.598 & 0.851 \\
\hline Milk (kg/d) & 37.5 & 37.3 & 36.3 & 37.9 & 1.28 & 0.903 & 0.219 \\
\hline $3.5 \%$ FCM $(\mathrm{kg} / \mathrm{d})$ & 34.6 & 35.2 & 34.3 & 36.7 & 1.06 & 0.132 & 0.262 \\
\hline Protein $(\%)$ & 2.99 & 2.99 & 3.01 & 3.07 & 0.07 & 0.181 & 0.476 \\
\hline Protein yield (g/d) & 1,114 & 1,106 & 1,086 & 1,156 & 33.9 & 0.332 & 0.114 \\
\hline $\operatorname{OS}^{4}(\%)$ & 5.74 & 5.73 & 5.71 & 5.67 & 0.04 & 0.092 & 0.505 \\
\hline OS yield $(\mathrm{g} / \mathrm{d})$ & 2,147 & 2,141 & 2,077 & 2,151 & 74.2 & 0.786 & 0.349 \\
\hline SCC (linear score) & 4.63 & 5.57 & 4.95 & 4.79 & 0.98 & 0.960 & 0.430 \\
\hline MUN' (mg/dL) & 15.3 & 14.9 & 15.6 & 14.8 & 0.38 & 0.518 & 0.495 \\
\hline $3.5 \% \mathrm{FCM} / \mathrm{DMI}$ & 1.56 & 1.58 & 1.55 & 1.67 & 0.04 & 0.036 & 0.125 \\
\hline
\end{tabular}

${ }^{1}$ Each treatment diet was supplemented with $150 \mathrm{mEq} / \mathrm{kg}$ of DM with varying ratios of supplemental K:Na (mEq/kg of DM) using potassium carbonate and sodium sesquicarbonate as cation sources.

${ }^{2}$ Linear orthogonal contrasts.

${ }^{3}$ Quadratic orthogonal contrasts.

${ }^{4}$ Other solids (lactose plus minerals).

pected to have equal DCAD concentrations, the 33:67 and 0:100 K:Na treatments had 32 and $46 \mathrm{mEq} / \mathrm{kg}$ of DM greater DCAD concentrations than the 100:0 and 67:33 K:Na treatments, respectively. This was due to a greater than expected measured $\mathrm{Na}$ content in these treatments, in which the expected increment in diet $\mathrm{Na}$ was 0.115 and $0.23 \%$ (+50 and $100 \mathrm{mEq} / \mathrm{kg}$ of DM $\mathrm{Na}$ ) compared with the measured increments of 0.18 and $0.32 \%$, which increased the DCAD from $\mathrm{Na}$ by 78 and $139 \mathrm{mEq} / \mathrm{kg}$ of $\mathrm{DM}$, respectively. As shown in experiment 1 , increasing DCAD by $50 \mathrm{mEq} / \mathrm{kg}$ of $\mathrm{DM}$ resulted in an average $\mathrm{FE}$ increase of only 0.02 units; thus, the $46 \mathrm{mEq} / \mathrm{kg}$ of DM DCAD difference between the highest and lowest DCAD treatments would not be large enough to cause a 0.11 -unit change in $\mathrm{FE}$, which was observed in this study.

Treatment had no effect $(P>0.05)$ on DMI, BW, or milk production (Table 4). As for milk composition, treatment had no effect on milk protein yield, protein percentage, OS yield, OS percentage, MUN, or SCC $(P>0.05)$. However, milk fat percentage and fat yield increased linearly with increased $\mathrm{Na}$ supplementation $(P<0.05)$, where fat percentage and fat yield were greatest $(3.36 \%$ and $1,156 \mathrm{~g} / \mathrm{d})$ in cows fed the $0: 100$ $\mathrm{K}: \mathrm{Na}$ treatment (in which $\mathrm{Na}$ was the sole supplemental cation). Despite a significant effect on milk fat percentage and yield, cation source did not affect $3.5 \%$ FCM $(P=0.132$ and 0.262 for linear and quadratic effects, respectively). Although we detected no change in DMI or $3.5 \%$ FCM individually, FE (FCM/DMI) increased linearly $(P=0.036)$ with increasing Na.

\section{DISCUSSION}

Previous studies have reported that DMI increases linearly in response to increasing DCAD concentrations using cation sources such as disodium phosphate, sodium bicarbonate, sodium carbonate, and $\mathrm{K}_{2} \mathrm{CO}_{3}$ (Delaquis and Block, 1995; Wildman et al., 2007b; Apper-Bossard et al., 2010). The results from experiment 2 confirm those results as DMI increased linearly from 22.3 to $23.6 \mathrm{~kg}$ as DCAD increased from 257 to $603 \mathrm{mEq} / \mathrm{kg}$ of DM. However, DMI was not affected by increased DCAD concentrations during experiment 1. It is possible that the DCAD effect on DMI observed in experiment 2 occurred as a result of the larger increments in treatment DCAD concentrations compared with experiment 1 (125 and $50 \mathrm{mEq} / \mathrm{kg}$ of DM, respectively). In experiment 3 , cation source did not significantly affect DMI. This result supports several other studies that showed that DMI is not affected by K:Na ratios (O'Connor et al., 1988; West et al., 1992; Wildman et al., 2007a). However, with the exception of the work of Wildman et al. (2007a) and Hu and Kung (2009), dietary DCAD was not held constant in previous experiments such that DMI effects of $\mathrm{K}, \mathrm{Na}$, and DCAD were confounded.

Previous work has shown that increasing DCAD concentration significantly increased milk production in lactating dairy cows (Sanchez and Beede, 1996; Tucker et al., 1988a; Hu and Murphy, 2004). However, DCAD had no effect on milk yield in experiments 1 or 2 . It is quite possible that the DCAD effect on milk production 
seen in other studies occurred because of larger increments in treatment DCAD concentrations (Delaquis and Block, 1995; Roche et al., 2005). For example, Wildman et al. (2007a) reported that increased DCAD $(\mathrm{Na}+$ $\mathrm{K}-\mathrm{Cl}$ ) improved milk yield; however, the increment in DCAD between the 2 dietary treatments was 250 $\mathrm{mEq} / \mathrm{kg}$ of DM. In a meta-analysis conducted by $\mathrm{Hu}$ and Murphy (2004), the authors reported a significant effect of DCAD on milk production, but the experimental DCAD concentrations ranged from -191 to 636 $\mathrm{mEq} / \mathrm{kg}$ of DM, with the majority of the milk production responses being the result of treatment means from cows fed very low DCAD $(\leq 100 \mathrm{mEq} / \mathrm{kg}$ of DM) diets, which would be atypical of diets fed on commercial dairies. In the current studies, treatment increments were only 50 and $125 \mathrm{mEq} / \mathrm{kg}$ of DM DCAD with the range in measured DCAD of 129 and $346 \mathrm{mEq} / \mathrm{kg}$ of DM in experiments 1 and 2 , respectively. It is difficult to compare the results from different DCAD experiments because of the lack of similarity between DCAD concentration ranges, cation sources, basal diets, and experimental animals (e.g., parity, stage of lactation, breed).

Although DCAD concentration did not affect milk yield in experiment 1 or 2 , DCAD has been shown to alter milk yield in previous studies, so a regression analysis was conducted on the study-adjusted milk yields from experiments 1 and 2 to determine which DCAD concentration maximized milk yield (Sanchez and Beede, 1996; Hu and Murphy, 2004). The results of the regression analysis suggest that milk yield was greatest $(39.51 \mathrm{~kg} / \mathrm{d})$ at a DCAD of $415 \mathrm{mEq} / \mathrm{kg}$ of DM $(P=$ $0.0444 ; R^{2}=0.6173 ;$ Figure 1$)$. The results observed in this regression analysis are similar to those reported by Sanchez and Beede (1996), which suggested that a DCAD concentration of $380 \mathrm{mEq} / \mathrm{kg}$ of DM maximized milk yield.

In experiment 3 , cation source had no effect on milk yield, which was similar to results that have been reported in other experiments (West et al., 1992; Sanchez et al., 1997; Hu and Kung, 2009). Wildman et al. (2007a) reported a quadratic effect of $\mathrm{K}: \mathrm{Na}$ ratio on milk production. At an average DCAD of $410 \mathrm{mEq} / \mathrm{kg}$, milk production was highest when the $\mathrm{K}: \mathrm{Na}$ ratio was 4:1 (Wildman et al., 2007a). Unlike the study by Wildman et al. (2007a), which included high $\mathrm{K}: \mathrm{Na}$ ratios (millequivalent basis) of $2: 1,3: 1$, and $4: 1$, the present study included supplemental K:Na ratios of only 1:0, $2: 1,1: 2$, and 0:1.0. Perhaps a cation source effect on milk production is visible only when the extreme $\mathrm{K}: \mathrm{Na}$ or Na:K ratios are tested. It has been suggested the overall DCAD concentration is more important than individual ion concentrations in altering milk production responses (Tucker et al., 1988a; West et al., 1992).
Milk fat percentage and yield $(\mathrm{g} / \mathrm{d})$ showed the greatest responses to DCAD and increased linearly with increasing DCAD concentration. In experiment 1 , the average milk fat percentage and yield increased by 0.27 percentage units and $112 \mathrm{~g} / \mathrm{d}$, respectively, as DCAD increased from 277 to $406 \mathrm{mEq} / \mathrm{kg}$ of DM. In experiment 1 , the mean milk fat content across treatments was only $2.74 \%$. This may have been due to the low NDF content of the corn silage being fed that resulted in total diet NDF of only $26.7 \%$. Although dietary NDF percentage was low during experiment 1 , the effects of DCAD on milk fat percentage and milk fat yield were similar between experiments 1 and 2 . For example, milk fat percentage increased 0.22 percentage units with the first increment in supplemental DCAD $(103 \mathrm{mEq} / \mathrm{kg})$. Similarly, milk fat yield increased by $112 \mathrm{~g} / \mathrm{d}$ in experiment $1(129 \mathrm{mEq} / \mathrm{kg}$ of DM DCAD increase) and 110 $\mathrm{g} / \mathrm{d}$ in experiment 2 with the first increment in supplemental DCAD (103 $\mathrm{mEq} / \mathrm{kg}$ of DM). Therefore, the results of experiment 1 and experiment 2 are consistent with each other despite the low dietary NDF percentage of the diets fed in experiment 1.

In experiment 2, milk fat percentage and yield increased by 0.34 percentage units and $127 \mathrm{~g} / \mathrm{d}$, respectively, as DCAD increased from 257 to $603 \mathrm{mEq} / \mathrm{kg}$ of DM. However, the majority of the response came with the first increment in DCAD using dietary $\mathrm{K}$ as the supplemental cation source at $368 \mathrm{mEq} / \mathrm{kg}$ of DM. Regression analysis using study-adjusted milk fat yields from experiments 1 and 2 suggests that predicted milk fat yield was greatest $(1,391 \mathrm{~g} / \mathrm{d})$ at a DCAD of 509 $\mathrm{mEq} / \mathrm{kg}$ of $\mathrm{DM}\left(P=0.0035 ; \mathrm{R}^{2}=0.9262 ;\right.$ Figure 2$)$.

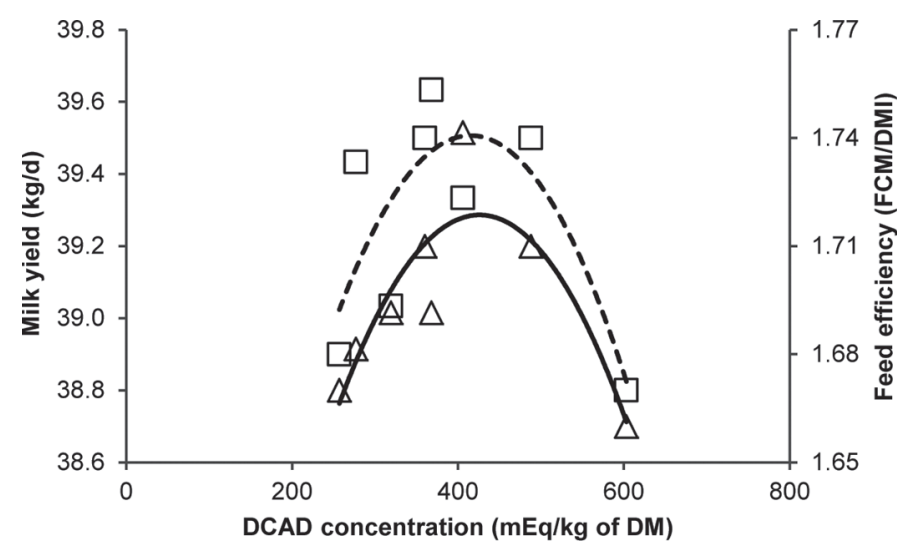

Figure 1. Quadratic regression equations for study-adjusted mean milk yield and feed efficiency (3.5\% FCM/DMI) in experiments 1 and 2. For milk yield $(\Delta ; \mathrm{kg} / \mathrm{d}), \mathrm{Y}=-0.00001933 \times \mathrm{DCAD}^{2}+0.0160 \times$ DCAD $+36.18\left(P=0.0444 ; \mathrm{R}^{2}=0.6173 ; \mathrm{n}=8\right) ;$ maximum milk yield occurred at a DCAD of $415 \mathrm{mEq} / \mathrm{kg}$ of DM. For feed efficiency $(\square), \mathrm{Y}$ $\left.=-0.00000183 \times \mathrm{DCAD}^{2}+0.00156 \times \mathrm{DCAD}\right)+1.387(P=0.0102$ $\left.\mathrm{R}^{2}=0.7670 ; \mathrm{n}=8\right)$; maximum feed efficiency occurred at a DCAD of $426 \mathrm{mEq} / \mathrm{kg}$ of $\mathrm{DM}$. 


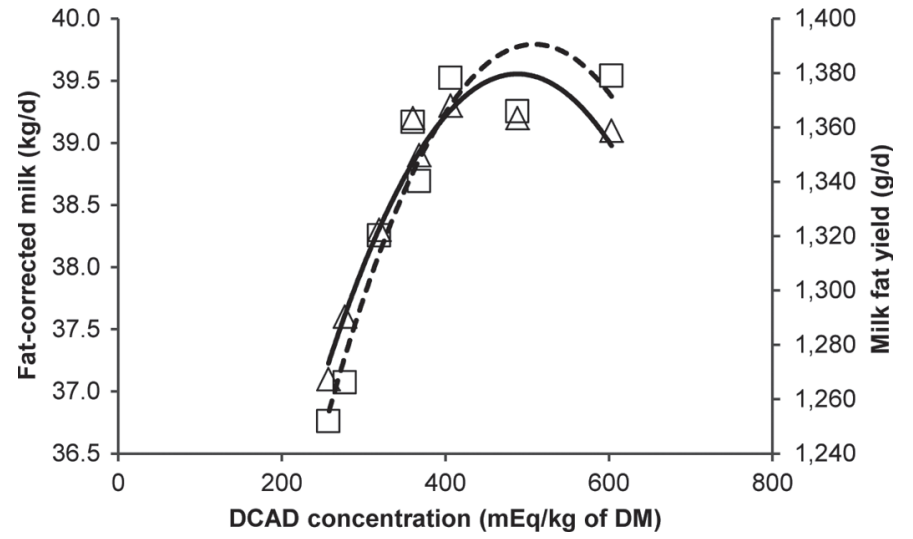

Figure 2. Quadratic regression equations for study-adjusted mean FCM and milk fat yields in experiments 1 and 2 . For FCM yield $(\Delta$; $\mathrm{kg} / \mathrm{d}), \mathrm{Y}=-0.00004359 \times \mathrm{DCAD}^{2}+0.0425 \times \mathrm{DCAD}+29.17(P=$ $\left.0.0011 ; \mathrm{R}^{2}=0.9409 ; \mathrm{n}=8\right)$; maximum $\mathrm{FCM}$ occurred at a DCAD of $488 \mathrm{mEq} / \mathrm{kg}$ of DM. For milk fat yield $(\square ; \mathrm{g} / \mathrm{d}), \mathrm{Y}=-0.00214478 \times$ $\mathrm{DCAD}^{2}+2.1817 \times \mathrm{DCAD}+835.8\left(P=0.0035 ; \mathrm{R}^{2}=0.9262 ; \mathrm{n}=\right.$ 8); maximum fat yield occurred at a DCAD of $509 \mathrm{mEq} / \mathrm{kg}$ of DM.

This result is consistent with the meta-analysis results published by $\mathrm{Hu}$ and Murphy (2004), which suggested that a DCAD concentration of $550 \mathrm{mEq} / \mathrm{kg}$ of $\mathrm{DM}$ would maximize milk fat yield.

Because of the increase in milk fat percentage, $3.5 \%$ FCM also increased linearly in response to increasing DCAD concentration in both experiments 1 and 2. Regression analysis using the study-adjusted FCM values from experiments 1 and 2 suggest that $3.5 \% \mathrm{FCM}$ was greatest $(39.6 \mathrm{~kg} / \mathrm{d})$ at a DCAD of $488 \mathrm{mEq} / \mathrm{kg}$ of DM $\left(P=0.0011 ; \mathrm{R}^{2}=0.9409 ;\right.$ Figure 2$)$. In their metaanalysis, Hu and Murphy (2004) suggested that the DCAD concentration required to maximize $4.0 \% \mathrm{FCM}$ was $490 \mathrm{mEq} / \mathrm{kg}$ of DM DCAD. Thus, the results from the current regression analysis support the previous suggestion that a DCAD of approximately $488 \mathrm{mEq} /$ $\mathrm{kg}$ of DM will maximize either $3.5 \%$ or $4.0 \%$ FCM $(\mathrm{Hu}$ and Murphy, 2004).

In experiment 3 , both milk fat percentage and fat yield $(\mathrm{g} / \mathrm{d})$ increased linearly when Na was substituted for $\mathrm{K}$ as the supplemental cation source. Fat percentage and yield increased by 0.30 percentage units and 118 $\mathrm{g} / \mathrm{d}$, respectively, by increasing dietary $\mathrm{Na}$ from 0.26 to $0.71 \%$ and reducing dietary $\mathrm{K}$ from 1.79 to $1.19 \%$. However, measured DCAD ranged from 416 to 458 $\mathrm{mEq} / \mathrm{kg}$ of DM as dietary $\mathrm{Na}$ increased and dietary $\mathrm{K}$ decreased, suggesting that part of the cation source response may have been due to a change in DCAD. Milk fat concentration increased with increasing DCAD in experiments 1 and 2 and with substitution of $\mathrm{Na}$ for $\mathrm{K}$ in experiment 3 . The magnitude of the change in milk fat concentration across DCAD and cation treatments were $0.27,0.34$, and 0.30 percentage units for experi- ments 1,2 , and 3 , respectively. However, the range in DCAD concentration across treatments was 129, 346, and $42 \mathrm{mEq} / \mathrm{kg}$ of DM, respectively. The relatively small change in DCAD in experiment 3 compared with the comparable magnitude in fat concentration responses across experiments suggests that $\mathrm{Na}$ substitution for $\mathrm{K}$, and not DCAD, was the principle reason for the increased milk fat concentration in experiment 3 .

Several studies have reported that milk fat concentration and fat yield are not affected by cation source (West et al., 1992; Sanchez et al., 1997; Hu and Kung, 2009). The NRC (2001) suggested that milk yield and DMI are not solely affected by individual dietary $\mathrm{Na}$ or $\mathrm{K}$ concentrations. Instead, changes in these responses may be the result of the interactive effect of $\mathrm{K}$, Na, and $\mathrm{Cl}$ because most physiological processes require a tightly regulated ratio of these cations (NRC, 2001). Therefore, if milk yield and DMI can be improved by manipulating Na:K ratios, it is quite possible that milk fat percentage and fat yield could also be increased by this method.

The dietary treatment that resulted in the highest milk fat production consisted of $1.19 \% \mathrm{~K}$ and $0.71 \%$ $\mathrm{Na}$, resulting in nearly equal contributions of $\mathrm{K}$ and $\mathrm{Na}$ on a milliequivalent per kilogram of DM basis (304 $\mathrm{mEq} / \mathrm{kg}$ of $\mathrm{DM}$ from $\mathrm{K}, 309 \mathrm{mEq} / \mathrm{kg}$ of $\mathrm{DM}$ from $\mathrm{Na}$ ). West et al. (1992) reported that cation source did not affect milk fat production but their treatment with the highest $\mathrm{Na}$ percentage $(0.87 \%)$ also contained $0.89 \%$ $\mathrm{K}$, resulting in a Na:K ratio of 1.66 on a millequivalent basis. A milk fat response to $\mathrm{Na}$ in the West et al. (1992) study may not have been detected due to a low overall K:Na ratio and the relatively low dietary K concentration. Therefore, the Na:K ratio may play a key role in altering the rumen environment and increasing milk fat production. The cause of the increased milk fat production with increased $\mathrm{Na}$ is unknown. However, it could be speculated that this is a rumen fermentation response, especially because of the known effects of absorbed rumen biohydrogenation intermediates on mammary lipogenesis (NRC, 2001; Bauman and Griinari, 2003). One could speculate that a "sodium effect" exists in the rumen that may have been responsible for increased milk fat production when the dietary $\mathrm{K}: \mathrm{Na}$ ratio is altered. However, because rumen data were not collected in experiment 3 , the potential mechanism of a sodium response cannot be addressed.

Although cation source did not significantly affect MUN concentrations, increasing DCAD concentration resulted in a significant decrease in MUN in experiment 2. Similarly, Spek et al. (2012) found that increasing dietary $\mathrm{NaCl}$ resulted in a significant decrease in MUN. Spek et al. (2012) found significant positive linear relationships between dietary sodium chloride and water 
intake, which resulted in an increased glomerular filtration rate and urine volume that corresponded with a decrease in MUN. It is possible that increasing dietary $\mathrm{K}$ in our study also increased water intake, which would result in increased urine volume and reduced MUN.

The main goal of experiments 1 and 2 was to determine the optimal DCAD concentration to maximize FE expressed as 3.5\% FCM per unit of DMI. In experiment 1 , DMI was not affected by DCAD concentration. Therefore, the denominator of the dairy FE equation (DMI) was similar between treatments. However, as DCAD concentration had a significant, linear effect on $3.5 \% \mathrm{FCM}$, FE increased 0.06 units with increasing DCAD and was maximal at the highest DCAD concentration of $406 \mathrm{mEq} / \mathrm{kg}$ of DM. In experiment 2, increasing DCAD increased both DMI and 3.5\% FCM, resulting in a curvilinear response to DCAD between diets ranging from 257 to $603 \mathrm{mEq} / \mathrm{kg}$ of DM DCAD. However, maximal FE occurred in the treatments with 360 and $488 \mathrm{mEq} / \mathrm{kg}$ of DM DCAD. Regression analysis using study-adjusted $\mathrm{FE}$ values from experiments 1 and 2 suggested that $\mathrm{FE}$ was maximized (1.72) at a DCAD concentration of $426 \mathrm{mEq} / \mathrm{kg}$ of $\mathrm{DM}\left(P=0.0102 ; \mathrm{R}^{2}=\right.$ 0.7670 ; Figure 1). This result is similar to the maximal FCM responses to DCAD reported by Hu and Murphy (2004) and Sanchez et al., (1994), which were 490 and $380 \mathrm{mEq} / \mathrm{kg}$ of DM DCAD, respectively.

The magnitude of the maximal FE response observed in experiments 1,2 , and 3 were $0.06,0.04$, and 0.11 , respectively, which were somewhat lower than reported in recent experiments using $\mathrm{K}$ supplementation. For example, Harrison et al. (2012) reported that FE improved by 0.11 units when DCAD was increased from 490 to $700 \mathrm{mEq} / \mathrm{kg}$ of DM with added dietary $\mathrm{K}$ as the cation source. Erdman et al. (2011) reported a 0.14-unit increase in FE by increasing DCAD in a corn silage-based diet from 255 to $336 \mathrm{mEq} / \mathrm{kg}$ of DM with added $\mathrm{K}_{2} \mathrm{CO}_{3}$. In addition, calculated $\mathrm{FE}$ values from published treatment means show that increasing DCAD from 291 to $537 \mathrm{mEq} / \mathrm{kg}$ of DM resulted in a 0.09-unit change in FE and increasing DCAD from 310 to $550 \mathrm{mEq} / \mathrm{kg}$ of DM resulted in a 0.12 -unit change in $\mathrm{FE}$ in diets containing 15 and $17 \% \mathrm{CP}$, respectively (Wildman et al., 2007a). The differences in FE responses might be attributed to the length of experimental treatment periods. In the present studies, dietary treatments were applied in 3-wk experimental periods, which are probably sufficient to allow for changes in milk fat percentage to be expressed (Rico and Harvatine, 2013) but insufficient to measure the full magnitude of milk production and DMI effects. In the studies of Erdman et al. (2011) and Harrison et al. (2012), treatments were applied at the beginning of lactation and lasted for 140 and 70 $\mathrm{d}$, respectively. Thus, under commercial conditions, the expected FE response to DCAD would be expected to be greater when dietary changes in DCAD are applied at the herd level and maintained continuously. Because of the potential magnitude of the change, we conclude that adequate DCAD can have a major effect on dairy FE.

\section{CONCLUSIONS}

In summary, an increase in milk fat concentration was the most consistent short-term response to increasing DCAD with dietary $\mathrm{K}$ and the substitution of $\mathrm{Na}$ for $\mathrm{K}$ as the cation source. At DCAD concentrations of 250 to $400 \mathrm{mEq} / \mathrm{kg}$ of DM, dietary K appeared to have no effect on feed intake, whereas at higher concentrations, feed intake was increased. The combination of the changes in milk fat concentration resulting in increased FCM suggested that maximal FE was achieved at a DCAD of $426 \mathrm{mEq} / \mathrm{kg}$ of $\mathrm{DM}$ when DCAD was increased using dietary $\mathrm{K}$ as the cation source. This value is consistent with other reports in the literature. Finally, dietary Na was shown to be more effective than dietary $\mathrm{K}$ in increasing milk fat in diets with DCAD of $400 \mathrm{mEq} / \mathrm{kg}$ of DM.

\section{ACKNOWLEDGMENTS}

The authors thank Arm \& Hammer Animal Nutrition (Piscataway, NJ) for partial support of these studies. In addition, the authors thank Michael Dwyer, Brian Spielmann, and the entire staff at the Central Maryland Research and Education Center (CMREC, Clarksville, MD) for their assistance in feeding, sample collection, and care of the experimental animals used in this study.

\section{REFERENCES}

Apper-Bossard, E., P. Faverdin, F. Meschy, and J. L. Peyraud. 2010. Effects of dietary cation-anion difference on ruminal metabolism and blood acid-base regulation in dairy cows receiving 2 contrasting levels of concentrate in diets. J. Dairy Sci. 93:4196-4210.

Bauman, D. E., and J. M. Griinari. 2003. Nutritional regulation of milk fat synthesis. Annu. Rev. Nutr. 23:203-227.

Buza, M. H., L. A. Holden, R. A. White, and V. A. Ishler. 2014. Evaluating the effect of ration composition on income over feed cost and milk yield. J. Dairy Sci. 97:3073-3080.

Delaquis, A. M., and E. Block. 1995. Dietary cation-anion difference, acid-base status, mineral metabolism, renal function, and milk production of lactating cows. J. Dairy Sci. 78:2259-2284.

Erdman, R. A., L. S. Piperova, and R. A. Kohn. 2011. Corn silage versus corn silage:alfalfa hay mixtures for dairy cows: Effects of dietary potassium, calcium, and cation-anion difference. J. Dairy Sci. 94:5105-5110.

Harrison, J., R. White, R. Kincaid, and E. Block. 2012. Effectiveness of potassium carbonate sesquihydrate to increase dietary cationanion difference in early lactation cows. J. Dairy Sci. 95:3919 3925 .

Hu, W., and L. Kung Jr.. 2009. Effect of dietary ratio of Na:K on feed intake, milk production, and mineral metabolism in mid-lactation dairy cows. J. Dairy Sci. 92:2711-2718. 
Hu, W., and M. R. Murphy. 2004. Dietary cation-anion difference effects on performance and acid-base status of lactating dairy cows: A meta-analysis. J. Dairy Sci. 87:2222-2229.

Hu, W., M. R. Murphy, P. D. Constable, and E. Block. 2007b. Dietary cation-anion difference effects on performance and acid-base status of dairy cows postpartum. J. Dairy Sci. 90:3367-3375.

NRC. 2001. Nutrient Requirements of Dairy Cattle. 7th rev. ed. National Academy Press, Washington, DC.

O'Connor, A. M., D. K. Beede, and C. J. Wilcox. 1988. Lactational responses to dietary magnesium, potassium, and sodium during winter in Florida. J. Dairy Sci. 71:971-981.

Rico, D. E., and K. J. Harvatine. 2013. Induction of and recovery from milk fat depression occurs progressively in dairy cows switched between diets that differ in fiber and oil concentration. J. Dairy Sci. 96:6621-6630.

Roche, J. R., S. Petch, and J. K. Kay. 2005. Manipulating the dietary cation-anion difference via drenching to early-lactation dairy cows grazing pasture. J. Dairy Sci. 88:264-276.

Sanchez, W. K., and D. K. Beede. 1996. Is there an optimal dietary cation-anion difference for lactation diets? Anim. Feed Sci. Technol. 59:3-12.

Sanchez, W. K., D. K. Beede, and J. A. Cornell. 1997. Dietary mixtures of sodium bicarbonate, sodium chloride, and potassium chloride: Effects on lactational performance, acid-base status, and mineral metabolism of Holstein cows. J. Dairy Sci. 80:1207-1216.

Sanchez, W. K., D. K. Beede, and M. A. Delorenzo. 1994. Macromineral element interrelationships and lactational performance: Empirical models from a large data set. J. Dairy Sci. 77:3096-3110.

Spek, J. W., A. Bannink, G. Gort, W. H. Hendriks, and J. Dijkstra. 2012. Effect of sodium chloride intake on urine volume, urinary urea excretion, and milk urea concentration in lactating dairy cows. J. Dairy Sci. 95:7288-7298.

Tucker, W. B., G. A. Harrison, and R. W. Hemken. 1988a. Influence of dietary cation-anion balance on milk, blood, urine, and rumen fluid in lactating dairy cattle. J. Dairy Sci. 71:346-354.

Tucker, W. B., Z. Xin, and R. W. Hemken. 1988b. Influence of dietary calcium chloride on adaptive changes in acid-base status and mineral metabolism in lactating dairy cows fed a diet high in sodium bicarbonate. J. Dairy Sci. 71:1587-1597.

USDA-ERS (USDA-Economic Research Service). 2013. U.S. Drought 2012: Farm and Food Impacts. Accessed June 19, 2014. http:// www.ers.usda.gov/topics/in-the-news/us-drought-2012-farm-andfood-impacts.aspx\#.U6MTEvldV8E.

USDA-NASS(USDA-National AgriculturalStatisticsService).2014. Milk cost of production estimates. Accessed June 12,2014.http://www.ers. usda.gov/data-products/milk-cost-of-production-estimates.aspx\#. U6LuR_ldV8F

West, J. W., K. D. Haydon, B. G. Mullinix, and T. G. Sandifer. 1992. Dietary cation-anion balance and cation source effects on production and acid-base status of heat-stressed cows. J. Dairy Sci. 75:2776-2786.

Wildman, C. D., J. W. West, and J. K. Bernard. 2007a. Effects of dietary cation-anion difference and potassium to sodium ratio on lactating dairy cows in hot weather. J. Dairy Sci. 90:970-977.

Wildman, C. D., J. W. West, and J. K. Bernard. 2007b. Effect of dietary cation-anion difference and dietary crude protein on milk yield, acid-base chemistry, and rumen fermentation. J. Dairy Sci. 90:4693-4700.

Wolf, C. A. 2010. Understanding the milk-to-feed price ratio as a proxy for dairy farm profitability. J. Dairy Sci. 93:4942-4948. 